\title{
INSTITUTIONAL PREREQUISITES FOR ORGANIZATIONAL AND ECONOMIC QUALITY ASSURANCE OF ECOSYSTEM SERVICES OF CITY PARKS
}

\author{
Nataliia Vernihorova'
}

\begin{abstract}
As of today, according to the classifications of ecosystem services, there were developed numerous methods of their assessment. At the same time, there are no studies on institutional support for ecosystems depending on their functional groups. If we want to achieve economic effects in our economic activity in the process of support and improvement of ecosystem functions, we need to know exactly what effects are desirable and which ecosystem functions are responsible for them. Therefore, the subject of research of the article is groups of ecosystem services of city parks and the possibility of their institutional support. The purpose of the article is to present a comprehensive approach to support for ecosystem services of city parks by diversifying directions of support by ecosystem functions. The article uses methods of theoretical cognition, namely: induction, deduction and systems analysis. The use of systems analysis is aimed at systematizing data on ecosystem functioning, and known ways of their institutional control and support. Conceptual data passes through the border of economics and ecology, and consist of known developments for the assessment of ecosystem services, their functional classification. The study and analysis of these sources allowed to develop a comprehensive approach to institutional support of park ecosystems, in order to obtain certain economic, ecological and social effects. The paper presents the specifics of institutional support of parks according to the landscape and geographical approach. Based on the analysis of the characteristics of parks of different categories, it was found that city parks in their organizational and economic support should embody the functions of public space, while maintaining its ecological significance for the city. Therefore, the results of the research indicate that due to its versatility, high-quality organization of the city park requires clear and responsible institutional support. A quality city park meets the social and ecological needs of the city, and ideally, contributes to the economic well-being of nearby facilities and areas. The popularity and economic importance of the park depends on the ability to meet all these needs and the quality of ecosystem services of the park. The practical significance of the study is that the diversification of institutional support of city parks by groups of ecosystem services will increase the efficiency of management and organizational apparatus in the field of park management and will improve the quality of services received by park visitors. Improvement of the quality of services will contribute towards the increase of the popularity of parks and, consequently, economic benefits. The originality of the article lies in the fact that the author proposed for the first time the support for park facilities by groups of ecosystem services. It is determined that city parks are characterized by the following functional groups of ecosystem services: regulatory, cultural and supportive. The qualitative component with regard to the city park provides not only its support as an ecosystem, but also the possibility of convenient consumption of these services by park visitors. Therefore, it is important for city parks to note the availability of infrastructure, which should be considered separately from the support of ecosystem services.
\end{abstract}

Key words: city parks, ecosystem services, support, institutional support, diversification.

JEL Classification: Q57

\section{Introduction}

The novelty of this research lies in the fact that the author proposed for the first time the diversification of institutional support for city parks in accordance with

Corresponding author:

${ }^{1}$ Institute of Market Problems and Economic\&Ecological Research of the National Academy of Sciences of Ukraine, Ukraine.

E-mail: natalivern93@gmail.com

ORCID: https://orcid.org/0000-0002-5968-4211 the functional groups of ecosystem services. Given that city parks are multifunctional areas, it is expected that they meet the ecological and social needs of the city. The main component that creates demand for

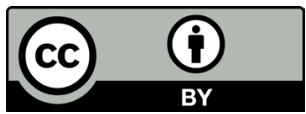

This is an Open Access article, distributed under the terms of the Creative Commons Attribution CC BY 4.0 
city parks is their ecosystems, which need support according to their functional groups. Therefore, in order to improve the quality of all these needs, it is important to develop organizational and institutional solutions in accordance with the functional classification of ecosystem services. The purpose of the article is to develop a comprehensive approach to institutional support of city parks based on the functional classification of ecosystem services. Scientific-research objectives of the article can be formed as follows:

- grouping of ecosystem services of parks by their functional groups,

- identification of the main objects and functions of ecosystem services, and the corresponding benefits for the state;

- identification of the object of influence by the institutions, to support certain groups of ecosystem services.

The research methodology consists of methods of theoretical cognition (induction, deduction and systems analysis). First of all, the analysis of existing research on the principles of classification of ecosystem services and the functions of parks in the city environment (Kucheriavyi, 2005; Solovii, 2016), including classic authors (Costanza, 1997; Millennium Ecosystem Assessment. 2005) and recent research (Xin Cheng, 2021; Jenssen, 2021; $\mathrm{Li}, 2021)$. Based on the analysis, it is proposed the following diversification of institutional support of parks: by categories of parks and by groups of ecosystem services. In the process of analysis, there were considered different parks according to their national importance, and, accordingly, functional purpose (diversification by categories of parks). Due to the fact that all parks are a cultural space, the use of a geographical approach is proposed while ensuring the quality of ecosystem services. Furthermore, there were considered the groups of ecosystem services and the corresponding effects they have (diversification by groups of ecosystem services). Accordingly, knowing the category of parks and their purpose, it is possible to regulate certain groups of ecosystem services to achieve the desired social, environmental and economic effects when using parks.

\section{Quality criteria for parks as a cultural space: landscape-geographical approach}

Usually ecosystem services are considered as "proposition from nature", "resource", "favorable natural conditions for economic development”. But at the same time, this resource is not infinite, and needs support from the state and society. Therefore, developing in practical terms the concept of quality environment of the park, it can be proposed the directions of support for ecosystem services of parks in accordance with:
1. Categories of parks and corresponding quality criteria.

2. Groups of ecosystem services (regulatory, cultural, support).

The actuality of supporting groups of ecosystem services lies in the increase of the efficiency of administrative regulation of the activity of parks, promotion of the development of relevant ecosystem services of the park, improvement of the quality of service.

Social and economic activities on the territory of parks comply with the requirements of cultural space. Cultural space means a part of geographical space (geospace) that differs in the specifics of cultural activities and features of cultural, informational and leisure needs of citizens, the interconnected elements of which are located in a certain territory (geotory) and develop over time (Law of Ukraine "On Culture", 2011). The requirements of cultural space depend on the type of park, its specialization and the value of ecosystems. Therefore, considering the park as a cultural space, it is important to use a geographical approach, according to which the concept of quality of ecosystem services for different categories of parks should be considered depending on their environmental, scientific and historical and cultural value. As of today, there are works in which landscape assessment of a natural object is used in the assessment and definition of goals in the long-term planning of protected areas, detection of regional features of the nature park (Hudzevich, Liubchenko, 2020). Therefore, in the context of the landscape-geographical approach, parks of national, regional and local significance should be divided (Figure 1).

Based on Figure 1, the administrative regulation of parks of national and regional importance should meet primarily environmental standards, research interests and cultural functions of these parks. Among the predominant groups of ecosystem services of these categories of parks, which have primary interest for state support, there can be marked regulatory and supportive ecosystem services.

For parks of local significance, priority ecosystem services should be determined in accordance with the species classification of the park, its goals and importance in the city system. Parks of local importance, especially megacities, are valuable for the entire range of ecosystem services. Their institutional regulation seems more complex in modern conditions. On the one hand, parks contribute to the improvement of microclimatic and ecological qualities of the city environment, and accordingly require compliance with environmental regulations.

On the other hand, city parks are an important element of public space. Modern conditions of the city environment have developed in such a way that a comfortable stay of a person outside his home, and 


\begin{tabular}{|c|c|c|}
\hline & Categories of parks & Quality criteria \\
\hline & 1. Parks of national significance & \multirow{4}{*}{$\begin{array}{l}\text { Compliance } \\
\text { environmental regulations, } \\
\text { provision of scientific- } \\
\text { research and cultural- } \\
\text { educational functions, } \\
\text { recreation with observance } \\
\text { of } \\
\text { regulations environmental }\end{array}$} \\
\hline \multicolumn{2}{|c|}{ 1.1 Natural objects - are national parks } & \\
\hline \multirow{2}{*}{\multicolumn{2}{|c|}{$\begin{array}{l}\text { 1.2 Artificially created environmental facilities - botanical } \\
\text { gardens, dendrological parks, zoological parks and parks- } \\
\text { memorials of garden and park art }\end{array}$}} & \\
\hline & & \\
\hline & 2. Parks of regional significance & \multirow{3}{*}{$\begin{array}{l}\text { Compliance with } \\
\text { environmental regulations, } \\
\text { recreation, conduct of } \\
\text { environmental educational } \\
\text { work }\end{array}$} \\
\hline \multicolumn{2}{|c|}{ 2.1 Natural objects - regional landscape parks } & \\
\hline & & \\
\hline & 3. Parks of local significance & \multirow{6}{*}{$\begin{array}{l}\text { Compliance with the } \\
\text { needs of the geosocial } \\
\text { system - providing } \\
\text { opportunities for } \\
\text { recreation of citizens, } \\
\text { maintaining the quality } \\
\text { of the natural } \\
\text { environment of cities, } \\
\text { entertainment and } \\
\text { leisure of all segments } \\
\text { of the population, the } \\
\text { needs of landscape and } \\
\text { architectural solutions }\end{array}$} \\
\hline \multicolumn{2}{|r|}{ 3.1 Multifunctional - parks of culture and recreation } & \\
\hline \multicolumn{2}{|c|}{3.2 Specialized } & \\
\hline \multicolumn{2}{|r|}{$\rightarrow$ a) natural objects - regional landscape parks } & \\
\hline \multicolumn{2}{|r|}{$\begin{array}{l}\text { b) artificially created objects of the reserve fund - } \\
\text { botanical gardens, dendrological parks, zoological parks, } \\
\text { parks-memorials of garden and park art; }\end{array}$} & \\
\hline & $\begin{array}{l}\text { c) objects of improvement of green economy of } \\
\text { settlements (parks of public use) }- \text { children's, sports, } \\
\text { exhibitional, memorial, waterparks, meadow parks, forest } \\
\text { parks, buffer parks }\end{array}$ & \\
\hline
\end{tabular}

Figure 1. Categories of parks and corresponding quality criteria

Source: compiled on the basis of the (Law of Ukraine "On the Nature Reserve Fund of Ukraine", 1992; Order "On approval of the Rules for the maintenance of greenery in the settlements of Ukraine", 2006)

especially recreation in favorable conditions require special creation and maintenance of greenery. The infrastructure of cities and their planning organization is mostly aimed at conducting efficient economic activities, which include: movement of people and connection with infrastructure (transit areas - streets, avenues, boulevards, roads, highways), location of public services, production, etc. (territories of economic subjects - streets, squares), and residential areas. Parks are often outside the interests of economic development and investors, although they are in high demand among visitors.

\section{Institutional support}

\section{for regulatory ecosystem services}

There are no targeted actions and programs to support ecosystems on the part of the state and institutions that take care of parks. Therefore, we propose to improve the administrative regulation of park facilities in accordance with the group of ecosystem services. For now, let's focus on city parks.
For each of the groups of ecosystem services (regulatory, cultural and support) that are specific to parks, it is possible to offer areas of support that focus on one or another element of the ecosystem that generates certain ecosystem services.

For regulatory ecosystem services of city parks, the main areas of support are clearly shown in Figure 2.

As can be seen from Figure 2, for the group of regulatory ecosystem services of city parks, there can be distinguished the following groups of institutional regulation:

- Administrative regulation and plant protection aimed at plant protection and biocenoses. The purpose of this area of support is to create favorable conditions for plant communities, so within these measures it is necessary to select plants based on their resilience, the need for living conditions, as well as the selection of plants to create symbiotic groups;

- Administrative regulation and control of sanitation, aimed at quality and species composition of greenery. The purpose of this area of institutional regulation is to create favorable conditions for human existence 
Regulatory services of city park ecosystems

Services Object of action Ecosystem service / state Benefit / feedback

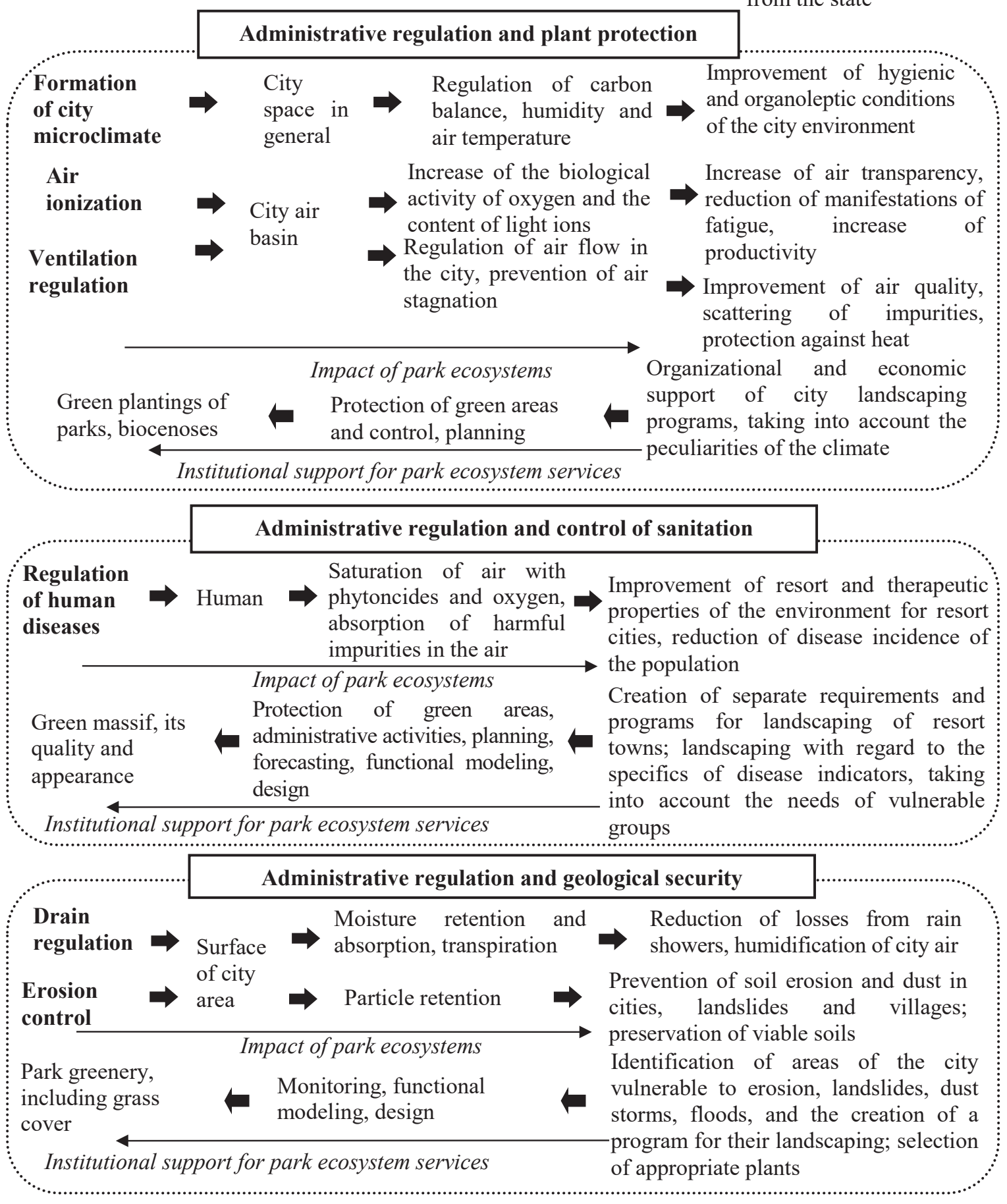

Figure 2. Main directions of institutional support for regulatory ecosystem services of city parks

Source: compiled by the author based on the analysis

(Kucheriavyi, 2005; Solovii, 2016; Young-Jae, 2018; Morsy, 2016; Pennino, 2016, Liu, 2012)

through greenery, improve the environment of the city, reduce common groups of human diseases. Given the purpose of this area, it is important to exclude plants harmful to human health, such as ragweed, male poplars, etc.;
- Administrative regulation and geological security, aimed at creating a safe geological environment in the city. The purpose of this area of support is to promote landscaping of vulnerable areas of the city, select plants with appropriate qualities. An example 
Cultural services of ecosystems of city parks

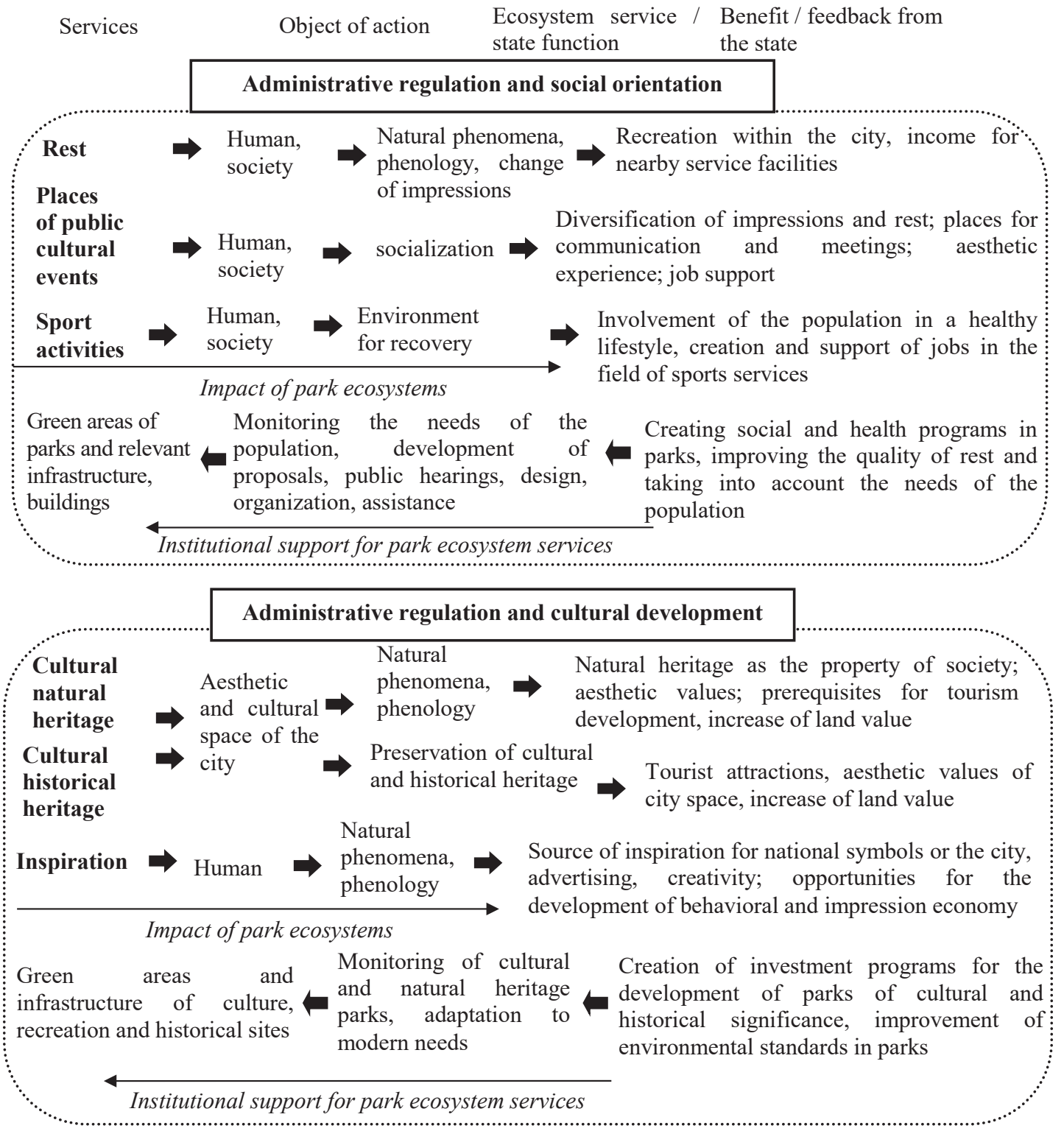

Figure 3. Main directions of institutional support for cultural ecosystem services of city parks

Source: compiled by the author based on the analysis

(Kucheriavyi, 2005; Solovii, 2016; Young-Jae, 2018; Morsy, 2016; Pennino, 2016, Liu, 2012)

of such support for ecosystem services is the creation of wetland parks on city territories. For example, the "Atlantic de Las Llamas Park" in Santander (Spain) (PROSTRANSTVO, 2021), or the Hong Kong Wetland Park in northern Ting Shui Wai (2021), which were designed to preserve wetland ecosystems and create an ecological mitigation zone.

It can be said that the object of state support for regulatory ecosystem services are green areas of parks, and the above three areas of support have their purpose. That is, it can be seen that the regulation of ecosystem services through the same object may have different meanings.

\section{Institutional support for cultural ecosystem services}

Let's consider the areas of support for cultural ecosystem services of city parks (Figure 3 ).

As can be seen from Figure 3, institutional areas of support for cultural ecosystem services include:

- Administrative regulation and social orientation, designed to create a favorable environment for recreation. The functioning of the park should be organized from the standpoint of the status of the territory as a public space, and include specially designed social programs, depending on the type and specialization of the park. Green plantations are 
the object of influence by state regulators, but their qualitative features are considered from the standpoint of benefit to society. This area includes the needs and safety of human health, as well as the possibility of implementing socially beneficial measures;
- Administrative regulation and cultural development aimed at maintaining the cultural value of parks. Institutional support is aimed at supporting those qualities that affect a person through impressions or inspiration. Therefore, the object of influence are units of greenery

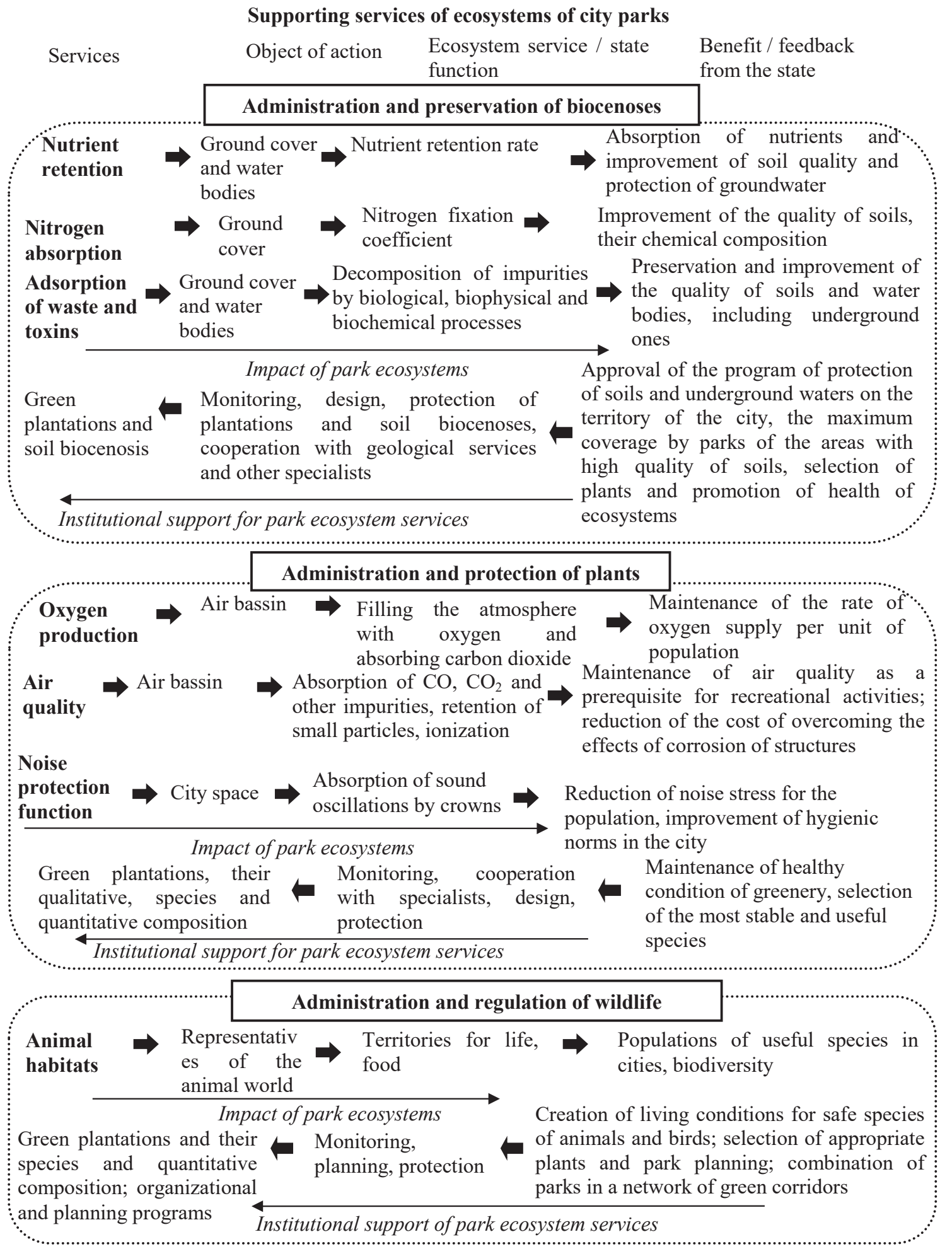

Figure 4. Main institutional areas of support and regulation of supporting ecosystem services of urban parks

Source: compiled by the author based on the analysis

(Kucheriavyi, 2005; Solovii, 2016; Young-Jae, 2018; Morsy, 2016; Pennino, 2016, Liu, 2012) 
in terms of their historical and cultural significance, as well as architectural complexes and objects.

Today in the city parks of Ukraine there are almost no permanent social programs, especially since they are not specified in the documents on the improvement of parks.

\section{Institutional support for supporting ecosystem services}

The basis for quality provision of park space is the institutional regulation of supporting ecosystem services. They are the basis for the preservation and development of cultural and regulatory ecosystem services, and create the main qualitative characteristics of the natural space of city parks (Figure 4).

It can be seen from Figure 4 that the main areas of regulation of supporting ecosystem services of parks are divided into:

- Administration and maintenance of biocenoses aimed at maintaining soil biocenoses through the selection of greenery, especially grass cover. This area should include soil protection programs, because as it is known, in the cities of the steppe zone of Ukraine may be high quality chernozems. Therefore, the creation of parks should be correlated with areas with valuable landscapes and the presence of groups of valuable biocenoses;

- Administration and protection of plants aimed at maintaining greenery, in order to improve such functions as: oxygen production, impact on air quality, noise protection properties. It provides for measures with regard to improve the health of greenery;

- Administration and regulation of wildlife, aimed at creating conditions in parks for the existence of birds, squirrels, hedgehogs. Both animal and human safety are important. Park areas should include groups of greenery that are far from people's recreation areas, or even out of reach. For example, groups of trees in a circle of low bushes provide opportunities for nesting and other forms of existence. At the same time, there should be no stray animals in the parks, and populations of squirrels and hedgehogs should be supervised by experts for signs of rabies and other dangerous diseases.

It can be seen that each of the groups of ecosystem services of urban parks requires different areas of support from the institutional maintenance. The object of influence remains almost unchanged - greenery and biocenoses of parks, but administrative decisions on the development of the park can take on different meanings and, accordingly, give different effects.

\section{Generalized principle of institutional support for city parks}

In Figure 5 we can summarize the principles of government regulation in the context of improving the ecosystem services of parks.

So, it can be seen that the quality of ecosystem services of parks and their diversity are provided primarily by such administrative areas as: protection of ecosystems and social orientation of park activities. Rich opportunities to offer ecosystem services of parks are a prerequisite for the implementation of various programs of recreation, rehabilitation and social activities. In Ukraine, almost both directions are absent, especially in city parks. The inclusion of parks in the socio-economic space of life of citizens in Ukraine takes place only in the areas of commercial benefit. Therefore, we can see how a poor understanding of the areas of quality support of parks and the lack of their socially oriented software leads to a qualitative impoverishment of ecosystem services.

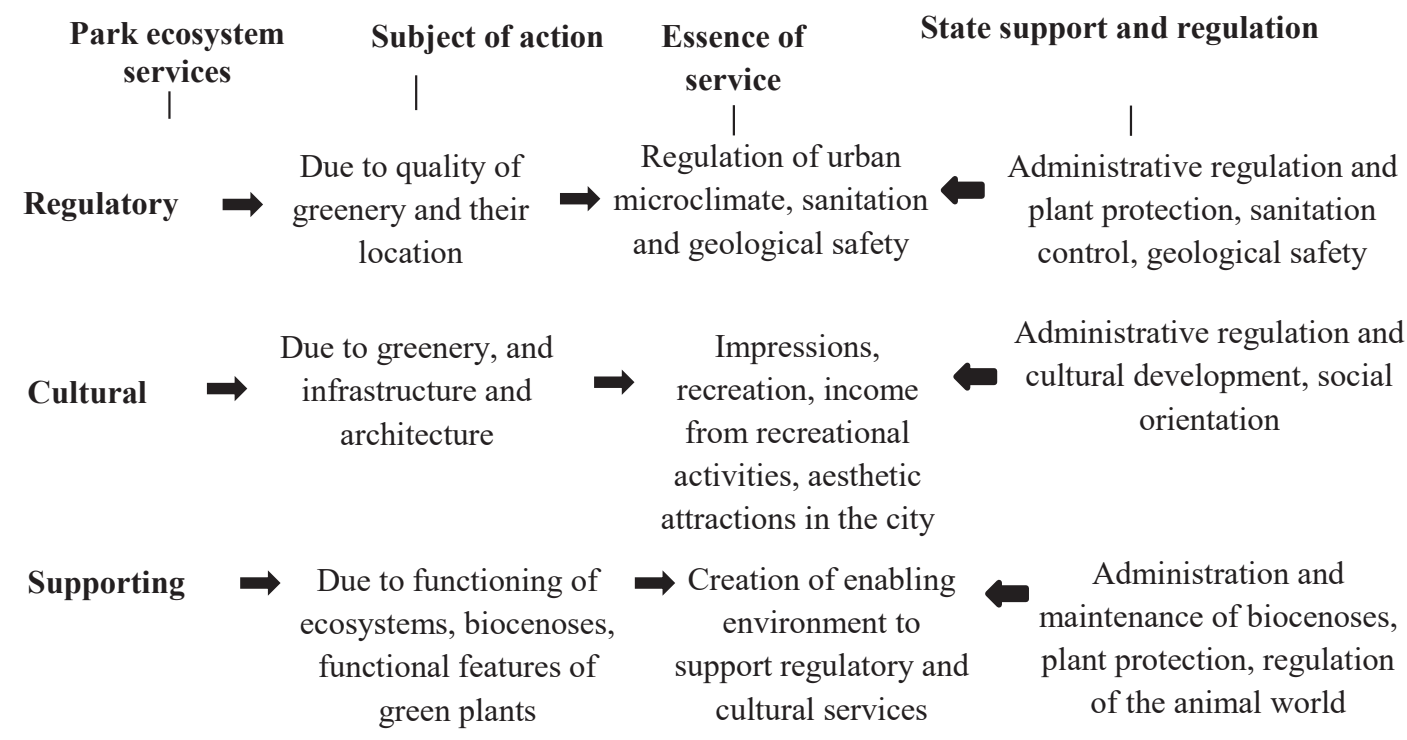

Figure 5. Principles of institutional regulation according to the groups of ecosystem services of parks

Source: compiled by the author 


\section{Conclusion}

In conclusion, it may be noted that the main prerequisite for organizational and economic quality support of ecosystem services of city parks is the comprehensive support of their ecosystems as the main resource for the creation of services. In addition, there must be an understanding of the impact of ecosystem groups on the social, ecological and economic environment of the city, to develop an optimal strategy for the development of parks with the desired effect. As of today, the park improvement system lacks specific solutions to support the ecosystem as a whole, or targeted support for a specific group of ecosystem services. That is why there is no clear understanding of the quality of city parks and ways to achieve it. Therefore, the following recommendations can be provided at the institutional level of the organization of park development:

- Diversification of administrative regulation, and organizational and economic support of parks in accordance with groups of ecosystem services;

- Expansion of cooperation of institutions and organizations on the balance of which the parks are listed, with botanists, ecologists and geologists in regards to creation of parks in vulnerable areas;

- Creation of a landscaping program in accordance with the problems of cities: sanitary, geological, climatic and specific diseases of local residents;

- Creation of parks in accordance with the social, environmental and economic needs of the city.

\section{References:}

Costanza, R. and other (1997). The value of the world's ecosystem services and natural capital. Nature, 387(6630), 253-260.

Hong Kong Wetland Park (2021). Electronic resources. Retrieved June 17, 2021 from: https://www.wigi.wiki/ wiki/uk/Hong_Kong_Wetland_Park

Hudzevich, A., \& Liubchenko, V. (2020). Landscape approach to taking into account the regional features of the organization of nature management of the protected area. Bulletin of V.N. Karazin's Kharkiv National University, Series "Geology. Geography. Ecology", 52, 119-129. Retrieved June 20, 2021 from: https://doi.org/ 10.26565/2410-7360-2020-52-09

Jenssen, M., Nickel, S., \& Schröder, W. (2021). Methodology for classifying the ecosystem integrity of forests in Germany using quantified indicators. Environmental Sciences Europe, 33(1), article no. 46. DOI: 10.1186/s12302-021-00478-y. Retrieved June 21, 2021 from: https://www.scopus.com/inward/record. uri?eid=2-s2.0-85104422202\&doi=10.1186\%2fs12302-021-00478-y\&partnerID $=40 \& \mathrm{md} 5=\mathrm{f} 4538980 \mathrm{dbc0} 1 \mathrm{~d} 29$ $32 \mathrm{e} 5 \mathrm{db} 29 \mathrm{~d} 0 \mathrm{~b} 55 \mathrm{ca} 4$

Kucheriavyi, V. P. (2005). Landscaping of settlements. Lviv: «Svit», 456 p.

Law of Ukraine "On Culture" (2011). Bulletin of the Verkhovna Rada of Ukraine, no. 24, 168 p.

Law of Ukraine "On the Nature Reserve Fund of Ukraine" (1992). Bulletin of the Verkhovna Rada of Ukraine, no. $34,502 \mathrm{p}$.

Li, Y., Fan, S., Li, K., Zhang, Y., \& Dong, L. (2021). Microclimate in an urban park and its influencing factors: a case study of Tiantan Park in Beijing, China. Urban Ecosystems, 24(4), 767-778.

Liu, C.-M., and other (2012). Experimental studies of the dilution of vehicle exhaust pollutants by environmentprotecting pervious pavement. Journal of the Air \& Waste Management Association, 62(1), 92-102.

Millennium Ecosystem Assessment (2005). Ecosystems and Human Well-being [Synthesis Peport]. Island Press, Washington DC, $160 \mathrm{p}$.

Morsy, M., Goodall, J., Shatnawi, F., \& Meadows, M. (2016). Distributed Stormwater Controls for Flood Mitigation in Urbanized Watersheds: Case Study of Rocky Branch Watershed in Columbia, South Carolina. Journal of Hydrologic Engineering, 21(11).

Order «On approval of the Rules for the maintenance of greenery in the settlements of Ukraine» (2006). Ministry of Construction, Architecture and Housing of Ukraine. Adoption on April 10, 2006, no. 105.

Pennino, M. J., McDonald, R. I., \& Jaffe, P.R. (2016). Watershed-scale impacts of stormwater green infrastructure on hydrology, nutrient fluxes, and combined sewer overflows in the mid-Atlantic region. Science of the Total Environment, 565, 1044-1053.

PROSTRANSTVO (2021). Park in the swamp or Cantabrian island of urban paradise. Retrieved June 17, 2021 from: https://www.prostranstvo.media/uk/park-na-boloti-abo-kantabrijskyj-ostrivecz-urban-rayu/

Solovii, I. (2016). Assessment of ecosystem services provided by the forests of Ukraine and proposals on payment mechanisms for ecosystem services. Retrieved June 17, 2021 from: www.enpi-fleg.org

Xin Cheng, Sylvie Van Damme, \& Pieter Uyttenhove (2021). A review of empirical studies of cultural ecosystem services in urban green infrastructure. Journal of Environmental Management, vol. 293. DOI: https://doi.org/10.1016/j.jenvman.2021.112895

Young-Jae, K., Lee, C., \& Jun-Hyun, K. (2018). Sidewalk Landscape Structure and Thermal Conditions for Child and Adult Pedestrians. International Journal of Environmental Research and Public Health; Basel, 15(1), 148. 